\title{
Nitelikli Kamu Görevlisi Yetiştirme: Ahlak Eksenli Bir Değerlendirme
}

\author{
Ahmet Hamdi AYDIN* Ömer ÇAMUR ${ }^{* *}$
}

\begin{abstract}
$\ddot{O} Z$
Kamu yönetimi, devletin en önemli araçlarından biri olarak, vatandaşların ortak nitelikteki ihtiyaçlarının giderilmesi amacıyla oluşturulan oldukça önemli bir yapıdır. Sunduğu hizmetlerle haklın yaşamı üzerinde doğrudan etkili olan kamu yönetimi, kendisinden beklenen görevleri yerine getirebilmek için birçok unsura ihtiyaç duymaktadır. Kamu görevlisi de kamu yönetiminin çok önemli bir unsurunu oluşturmaktadır. Kamu görevlisi kamu yönetiminde insan unsurunu ifade etmektedir. İnsan unsurundan elde edilecek başarı kamu yönetiminin başarısını doğrudan etkilemektedir. Çünkü insan unsuru kamu yönetiminin diğer tüm unsurlarını yönetsel süreçte verimli veya verimsiz kılabilmesinden dolayı oldukça önemli bir yere sahiptir. Insan unsurundan başarının elde edilmesi ise ahlakı gerekli kılmaktadır. Zira ahlak, tüm tarihsel dönemlerde nitelikli insan profilinin oluşturulması hususunda üzerinde birliktelik sağlanan temel değerlerin başında gelmektedir. Ahlak, iyi ve doğru temelinde insanın bireysel anlamda yetkinliğe ulaşmasını ve nihayetinde kamil bir toplumun inşasını amaçlamaktadır. Ahlakın bu amacı aynı zamanda kamu yönetiminde nitelikli kamu görevlisi yetiştirebilmenin de anahtarıdır. Bu bilgiler ışığında yapılan bu çalışmada öncelikle 'ahlak', 'kamu yönetimi' ve 'kamu görevlisi' kavramları açıklanacaktır. Çalışmanın devamında ise ahlakın nitelikli kamu görevlisi yetiştirmedeki önemi ortaya konmaya çalışllacaktır.
\end{abstract}

Anahtar Kelimeler: Ahlak, Kaти Görevlisi, Kaти Yönetimi

JEL Sinıflandirmast: M12, H83

\section{Training Competent Public Officials: An Ethics-Oriented Evaluation}

\begin{abstract}
Public administration, as one of the primary means of the state, is a highly important structure established to meet common needs of citizens. Having a direct impact on people's life with the services it provides, public administration requires many elements to perform duties expected of it. Public officials constitute a vital part of public administration. They represent human factor in public administration. Accomplishment gained though human factor affects the success of public administration directly, because human factor has a significant place due to its ability to render all the other factors in public administration productive or unproductive in the administrative process. Ethics is essential for success through human factor; because ethics is the primary basic value that is agreed on to create a qualified individual profile in all historical periods. Ethics aims for humans to achieve individual competence on the basis of good and right, and to build a perfect society ultimately. This aim of ethics is also key to raising qualified public officials in public administration. In view of such information, this study first explains the concepts of 'ethics', 'public administration'
\end{abstract}

\footnotetext{
* Prof. Dr., Kahramanmaraş Sütçü İmam Üniversitesi İktisadi ve İdari Bilimler Fakültesi, Kamu Yönetimi Bölümü, ahaydin@ksu.edu.tr, ORCID bilgisi: 0000-0002-1886-7951

** Dr. Öğretim Üyesi, Bingöl Üniversitesi Sağlık Hizmetleri Meslek Yüksekokulu, Yönetim ve Organizasyon Bölümü, ocamur@bingol.edu.tr, ORCID bilgisi: 0000-0001-6447-1475
} 
and 'public official'. The study then attempts to indicate the important role of ethics in training competent public officials.

Key Words: Ethics, Public Official, Public Administration

JEL Classification: M12, H83

\section{GİRIŞ}

Ahlak, iyi ve doğru temelinde en iyi yaşama ve davranış biçimini ortaya koyan ve ideal hayatın temeli olan davranış kurallarıdır. Ahlak insanın iyi özellikler kazanarak faziletleri elde etmesini ve kötülüklerden uzaklaşmasını sağlamaya çalışan hem bireysel hem de toplumsal bir değerdir. Ahlak insana bireysel yaşamda rehberlik ederek insanın yetkinliğe ulaşmasını ve nihayetinde toplumsal huzurun sağlanmasını amaçlayan yegane unsurdur. Ahlakın sahip olduğu bu amaç kamu yönetimi için ayrıca önemlidir.

Kamu yönetimi vatandaşların ihtiyaç duyduğu hizmetlerin üretilmesi amaciyla faaliyet göstermektedir. Kamu yönetimi kendisinden beklenen hizmetleri üretebilmesi için çeşitli elemanlara ihtiyaç duymaktadır. Kamu yönetiminin en önemli elemanlarından birini kamu görevlileri oluşturmaktadır. Kamu yönetiminde insan unsurunun diğer tüm unsurları da etkileyebilecek nitelikte bir eleman olması, diğer tüm elemanları yönetsel faaliyet sürecinde verimli ve verimsiz kılabilmesi, belirlenen amaçlar doğrultusunda yönetim faaliyetini gerçekleştirebilmesi gibi özelliklerinden dolayı, insan unsuru, kamu yönetimi içerisindeki yerini ve önemini daima korumuştur ve korumaktadır.

İnsan unsuru, kamu yönetiminde kamu görevlisi veya kamu personeli olarak adlandırılmaktadır. Kamu personeli çok geniş bir anlamı ile devlete ait tüm kurumlarda çalışan ve hukuki durumları itibariyle birbirlerinden farklı olan tüm görevlileri ifade etmektedir. Kamu personeli, kamu yönetiminin amac1 doğrultusunda faaliyet göstermesinde doğrudan etkili olan önemli bir unsurdur.

Kamu yönetiminde insan unsurunun etkin bir şekilde kullanılması, insanın nitelikli bir hale gelmesi ile mümkündür. İnsanın nitelikli bir hale gelmesi ise sahip olduğu tüm özelliklerinin yanı sıra ahlakı gerekli kılmaktadır. Zira kamu yönetiminde ahlaki faziletleri kendisinde bulundurmayan bireyler kamu yönetiminin faaliyetlerinin aksamasına ve gerek kamusal gerekse toplumsal yaşamda birçok sorunun yaşanmasına neden olmaktadırlar. Dolayısıyla verimli bir kamu yönetimi için yetiştirilen kamu görevlisinin ahlaki niteliklere sahip olması gerekmektedir.

$\mathrm{Bu}$ çalışmada öncelikle ahlak, kamu yönetimi ve kamu görevlisi kavramlarının ne anlama geldikleri açıklanacaktır. Çalışmanın devamında ise nitelikli kamu görevlisi yetiştirme hususu ahlak ekseninde incelenecek ve ahlakın nitelikli personel yetişt111irmedeki önemi tartışlacaktır.

\section{KAVRAMSAL ÇERÇEVE}

\section{A. Ahlak}

Ahlak, insanlığın var oluşuyla birlikte varlığını devam ettiren, hem insani hem de felsefi bir konudur. Hatta diyebiliriz ki, ilk peygamber Hz. Adem'e Allah (c.c.) tarafindan gönderilen ilahi emirlerle birlikte ahlak kuralları daima var olmuştur (Erdem, 1990: 225). Tüm ulusların yaşamlarında ahlaki açıdan, neyin 
ödül ve övgüye değer olduğu veya tersine neyin kötü ve itilmesi gereken bir şey olarak belirtildiğini bildiren anlatımlar bulunmaktadır. Bütün dinler, dünya görüşleri, hukuki düzenler, töreler ve alışkanlıklar, insanların neyi yapmaları ve neyi yapmamaları gerektiği üzerine birtakım inanışlarla doludur (Heimsoeth, 1978: 12). Görüldüğü üzere insanlar, ilk medeniyetlerin kuruluşundan beri, kendi hareketlerinin değerlendirilmesi temeline dayanan ahlak ile uğraşmışlardır. Sokrates tarafından temelleri atılan ve değerler felsefesinin önemli bir dalı olan ahlaka, yaşamımızın her anında olmakla birlikte her tarihsel dönemde ve her insan topluluğunda mutlaka rastlanmaktadır (Topçu, 2015a: 15; Doğan, 2014: 115; Özlem, 2004: 17-18).

Böylesi eski ve üzerinde çokça düşünülmüş olan bir kavramın ne olduğunun ortaya konması elbette zordur. Kavramın farklı disiplinler tarafından incelenmesi durumu daha da karmaşık kılmaktadır. Lakin tarihsel süreç içerisinde ahlak ile ilgili ortaya konan düşünceler bizlere ahlakın ne olduğu ile ilgili geniş bilgiler sunmaktadır. Kelime olarak dilimize Arapçadan geçen ve "hulk" kelimesinin çoğulu olan ahlak, tabiat, huy ve karakter gibi anlamlara gelmektedir (Akseki, 2016: 26).

Ahlak kavramı kelime anlamının ötesinde deruni bir nitelik arz eden ender kavramlardan biridir. İlk çağlardan günümüze kadar gerek bireysel yaşamın gerekse bir bütün olarak toplumsal yaşamın temelini oluşturan bir kavram olarak varlığını sürdürmüştür. Ahlak, temelde bireysel yetkinliğe ulaşma, sonrasında ise bireysel yetkinliğe ulaşmış bireylerden kemal bir toplumun inşasına kadar uzanan geniş bir olguyu ifade etmektedir. Nitekim tarihsel süreç içerisinde ahlak ile ilgili düşünceler ortaya koyan Sokrates, Platon, Aristoteles, Farabi, İbn Haldun, Gazali, İbn Sina, Nasıruddin Tusi, Kınalızade Ali Çelebi ve birçok diğer düşünürün üzerinde uzlaştıkları temel unsur bu olmaktadır. Bu hali ile ahlak, Cevizci'nin ifadeleriyle, "toplumların ayrılmaz bir parçasını oluşturan, hatta bu toplumlarda yaşayan insanların sadece birbirleriyle olan ilişkilerini düzenlemek açısından değil, fakat bir bütün olarak dünyalarını şekillendirmek yönünden de büyük bir önem arz eden manevi yapıyı" ifade etmektedir (2018: 16).

Ahlak ile ilgili birçok tanımda bulunmak mümkündür. En iyi yaşama ve davranış biçimini ortaya koymaya çalışan, iyiliğin ve ideal hayatın temeli olan ahlak, öncelikle, iyi-kötü değerlerinin ortaya koyduğu tutum ve davranış kurallarını ifade etmektedir (Bulut, 1996: 97; Kalın, 2015: 100).

Ahlak, insanda doğuştan var olan, terbiye ile değişmeye ve düzelmeye elverişli bulunan belli bir takım ruhi ve kalbi hal ve nitelikleri ifade etmektedir (Uludağ, 2018: 13).

Ahlak, insanı iyi özellikler edinmeye sevk eden, faziletleri kazanmaya ve kötülüklerden uzaklaşmaya yönelten ve bu yolda ona rehberlik eden bir yoldur (Mahfuzi, 2015: 16).

Ahlak, "belli bir dönemde belli insan topluluklarınca benimsenmiş olan, bireylerin birbirleriyle ilişkilerini düzenleyen törel davranış kurallarının, yasalarının, ilkelerinin toplamı"dır (Akarsu, 1998: 18). 
Bir başka tanıma göre ahlak, "tek kişinin veya bir insan topluluğunun belli bir tarihsel dönemde belli türden eğilim, düşünce, inanç, töre, alışkanlık, görenek vb. ve bunlarda içerilmiş olan değer, buyruk, norm ve yasaklara göre düzenlenmiş ve bu haliyle gelenekleşmiş, yerleşmiş yaşama biçimi” dir (Özlem, 2004: 16-17).

Her ne kadar yazın literatüründe ahlak ile ilgili yapılmış tanımlarda ahlakın belirli bir dönemde ve belirli bir topluluk için geçerli olduğu ifade edilse de ahlakın evrensel bir yönü de bulunmaktadır. Zira Güngör'e (1997: 32) göre adaletli davranmak, dürüst olmak, düşkünlere yardım etmek gibi her çağda ve zamanda geçerli olan mutlak ahlaki öğeler bulunmaktadır.

Özetle ifade etmek gerekirse ahlakın dört farklı alana denk düştüğü görülmektedir. Bunlardan ilki, ahlakın toplum tarafindan konmuş ve benimsenmiş davranışların tamamı olduğu; ikincisi, belli kurallara bağlı olarak sergilenen davranışların tümü; üçüncüsü, pek nadir kullanılan törebilimi; dördüncüsü ise, ahlakın bir felsefe, yani etik olduğudur (Gündüz, 2016: 3).

Ahlak, kural koyucu bir tutum ile davranışlarımıza yön vermeye çalışır. $\mathrm{Bu}$ özelliğinden dolayı ona eylem felsefesi de denilebilmektedir. Ahlak insanlara bir takım eylem biçimlerinin varlığını duyurur ve uyulması gereken formüller geliştirir. Ahlak, "iyi” kavramının belirlenmesinde bireysel sorumlulukları veya yükümlülükleri tartışır ve insana bugünü ve geleceğiyle ilgili doğruları göstermeye çalışır (Timuçin, 2010: 17-18).

İbn Haldun'a göre insanlar yaşayabilmek ve varlıklarını sürdürebilmek ve temel nitelikteki ihtiyaçlarını karşılayabilmek için bir araya gelmektedirler (İbn Haldun, 2011: 417). İbn Haldun bu durumun neticesini insanın toplumsal bir varlık olmasına bağlamıştır. Dolayısıyla ahlak, insanın toplumsal bir varlık olmasının zorunlu bir sonucudur. Çünkü ahlakın konusu, diğer insanlarla kurmuş olduğumuz ilişkilerdir (D’Alembert, 2000: 62). Bu doğrultuda ifade edilebilir ki ahlakın temel amacı, kendimizde ve başkalarında insanı geliştirmek ve insana gerçekten yaraşır hayat şartlarını sağlamaktır (Meriç, 2008: 106). Bu durum öncelikle bireysel ve sonrasında ise toplumsal olarak kendisini göstermektedir. Şöyle ki ahlak, birinci şahısta bir değer taşır. Bu evrenseldir. Diğer bir ifade ile tüm insanlar için geçerlidir (Comte-Sponville, 2006: 22).

İnsan yaşamı için oldukça önemli olan ahlak, kamu yönetimi için de vazgeçilmez bir olgudur. Temelde vatandaşların ihtiyaçlarını karşılamak amacıyla faaliyet gösteren kamu yönetimi, ahlaki bir bakış açısı ile desteklenmedikçe amacı doğrultusunda faaliyet gösteremez. Konunun daha iyi anlaşılabilmesi için "kamu yönetimi" kavramının ve kamu yönetiminin çok önemli bir unsuru olan "insan" unsurunun ne olduğunun ortaya konması gerekmektedir.

\section{B. Kamu Yönetimi}

Kamu yönetimi, insanların toplumsal bir hayat sürmelerinin doğal bir sonucudur ve kamu yönetiminin insanlık tarihi ile başlayan köklere sahip olduğu ifade edilebilir (Parlak, 2016: 7). Dolayısıyla kamu yönetimi tarihsel süreç 
içerisinde üzerinde çokça düşünülmüş ve hakkında çeşitli düşünceler öne sürülmüş kavramlardan biridir. Bu durum kamu yönetiminin ne olduğu ile ilgili birçok bilginin varlığını beraberinde getirmektedir. Bunu düşünsel bir birikim süreci olarak değerlendirmek mümkündür. Lakin bu süreç bitmiş değildir ve varlığını güçlü bir şekilde devam ettirmektedir. Eryılmaz'a (2015: 9) göre toplumların hacim ve ilişkilerindeki yoğunluk bakımından genişlemesi kamu yönetiminin de yapı ve işleyiş olarak büyümesine ve görev alanının genişlemesine neden olmaktadır. Bu durum kamu yönetimi kavramının çok çeşitli tanımlarının yapılmasını gerekli kılmaktadır. Her bir tanım kamu yönetiminin çeşitli görünümlerini yansıttığı gibi kamu yönetimi alanının çok kapsamlı ve güçlü bir alan olduğunu da göstermektedir.

Kamu yönetimi gerek teorik gerekse pratik olarak toplum, devlet ve hükümetin yapısı ve işleyişi olmak üzere geniş bir alan ile ilgilidir. Aralarında farklılıklar bulunmasına rağmen özel yönetim ile var olan ilişkisinden dolayı kamu yönetimi bazen özel yönetimi de kapsayacak biçimde tanımlanabilmektedir. Ancak White'ın "kamu yönetimi, kamu politikalarının uygulanması veya yerine getirilmesi amacıyla yapılan tüm uygulamalardan oluşur" ifadesi kamu yönetiminin mahiyetini belirten önemli bir düşüncedir (Aydın, 2016: 33). Bu düşünce doğrultusunda ifade edilebilir ki kamu yönetimi genel bir ifade ile devlet ve onun yürütme gücünün fonksiyonel alanını ifade etmektedir.

Kamu yönetimi çok basit bir tanıma göre devlet tarafindan yönetim anlamına gelmektedir. $\mathrm{Bu}$ tanımı devlet teşkilatını oluşturan birimler ve kamu kurumları tarafindan yönetim şeklinde anlamak gerekmektedir (Aydın, 2016: 37).

Kamu yönetimi, yönetimin belirli sınırları içerisinde bulunan spesifik bir alanı olarak tanımlanabilir. $\mathrm{Bu}$ alanda daha çok temsil yönü güçlü olan siyasal organlarca belirlenen kamu politikalarının yürütülmesi süreçleri görülmektedir (Tortop vd., 2017: 267).

Kamu yönetimi dar ve geniş anlamda tanımlanabilir. Dar anlamda kamu yönetimi, devletin faaliyet alanı içerisinde yalnızca "yürütme" alanına ilişkin yönetsel kuruluş ve faaliyetleri kapsamaktadır. Geniş anlamda ise, "yasama" ve "yargı" alanlarındaki yönetsel kuruluşlar ile faaliyetleri de kapsayan bir alanı ifade etmektedir (Gözübüyük, 2015: 1).

Kamu yönetiminin temelde yapısal ve işlevsel olmak üzere iki yönü bulunmaktadır. Kamu yönetiminin yapısal yönü, devletin örgütsel görünümü ile ilgilidir. Tüm devletler yasalarca belirlenen görevleri yerine getirebilmek için yerel ve ulusal düzeyde çeşitli örgütlenmelere gitmektedirler. Bu örgütlenme kamu yönetiminin yapısal boyutunu oluşturmaktadır. Kamu yönetiminin işlevsel yönü ise yasaları ve kamusal politikaları uygulama süreci ile ilgilidir. Genel kurallar bu süreç aracılığıyla özel olaylara uygulanarak kararlara dönüşürler (Turan, 2016: 55).

Kamu yönetimi ile ilgili yapılan tanımlar ve açıklamalar incelendiğinde kamu yönetiminin genel manada üç anlamı olduğu söylenebilir. Birincisi devlete veya kendisine bağlı kuruluşlarda çalışan kişilerin ve kümelerin davranışlarıyla 
ilgili bir alan olduğu; ikincisi devletin sahip olduğu amaçları gerçekleştirecek biçimde bir araya gelmiş insan gücü ve araç-gereç ile bunların idaresi olduğu; üçüncüsü ise kamusal politikaların oluşturulmasında, siyasal karar organlarına teknik destek sağlayan ve bu politikaları uygulayan örgütler bütünü şeklinde tanımlamaktadır (Bozkurt vd., 1998: 133).

\section{Kamu Görevlisi}

Kamu yönetimi kendisinden beklenen hizmetleri üretebilmek için çeşitli elemanlara ihtiyaç duymaktadır. Vatandaşlara hizmet sunmakla ve kamusal düzeni kesintisiz olarak sürdürebilmekle görevli olan kamu yönetiminin, halk, örgüt, kamu politikası, norm düzeni, mali kaynak ve kamu görevlileri gibi elemanları bulunmaktadır. Şüphesiz sayılan elemanların hepsi kamu yönetimi için oldukça önemlidir ve ancak bu elemanların varlı̆̆ ile kamu yönetimi görevlerini yerine getirebilmektedir. Lakin kamu yönetiminde insan unsurunun diğer tüm unsurları da etkileyebilecek nitelikte bir eleman olması, diğer tüm elemanları yönetsel faaliyet sürecinde verimli ve verimsiz k1labilmesi, belirlenen amaçlar doğrultusunda yönetim faaliyetini gerçekleştirebilmesi gibi özelliklerinden dolayı, insan unsuru, kamu yönetimi içerisindeki yerini ve önemini daima korumuştur ve korumaktadır.

Öncelikle ifade etmek gerekir ki ahlakın konusu insandır ve çalışmanın ahlak ile bağlantısından dolayı 'insan' kavramı ile ilgili gerekli bilgilerin verilmesi ve daha sonra kamu yönetimi ve kamu görevlisi açısından değerlendirilmesi önem arz etmektedir.

Şeriati (1997: 8-9), çağdaş insan için temel sorunun yine insanın kendisi olduğu yargısından hareketle, insanın mutlaka tanımlanması gerektiğini ifade etmiştir. Ona göre insanın ne olduğunun ve ne olması gerektiğini kavrayamamak kültür, eğitim, öğretim, ahlak ve toplumsal ilişkileri düzeltme konusundaki bütün çabaları boşuna çıkarmaktadır.

İnsanın ne olduğu üzerinde birçok felsefi çalışma yapılmasına rağmen ortak bir kanıya varılamamıştır. Sözlük anlamı ile "toplum halinde bir kültür çevresinde yaşayan, düşünme ve konuşma yeteneği olan, evreni bütün olarak kavrayabilen, bulguları sonucunda değiştirebilen ve biçimlendirebilen canlı" olarak ifade edilen insan, farklı açılardan incelenen kavramlardan biridir (www.tdk.gov.tr, 23.11.2018). Biyolojik açıdan insan, milyonlarca hücreden oluşmuş oldukça karmaşık bir organizasyonu ifade etmektedir. Fizyolojik açıdan insan hücre, doku, organ ve sistemlerden oluşan ve bu yapılar arasında iletişimin sinir sistemi ile sağlandığı yapıdır (Ünsal, 2017: 11).

Esasen insan kavramı ile ilgili olarak yapılan açıklamalar incelendiğinde, genellikle herkesin insanı kendi bakış açısı ve inancı doğrultusunda değerlendirdiği ve insanı bir tanıma oturtmaya çalıştığı görülmektedir. Örneğin doğa bilimleri insanı doğanın bir uzantısı ve parçası olarak görmekte ve insanı da hayvan gibi ruhsal ve maddi olmak üzere iki bölümden oluşan bir canlı şeklinde tanımlamaktadırlar. Bu anlayışa göre hayvanlar ile insanlar arasında bir fark bulunmamaktadır (Aral, 2014: 17). Materyalistler açısından insan, imkanlarla donatılmış, üstün yetenekli ve şuurlu bir varlık olarak, bilinçsiz, doğaya tabi ve 
sadece mekanik olarak ayarlanan bir canlı olarak değerlendirilmiştir. İnsan İslami açıdan değerlendirildiğinde ise tüm yaratılanlar içerisinde yaratılmışların en üstünü olan varlığı ifade etmektedir. Onun bu üstünlüğü, inanma, tefekkür, dürüstlük, toplumsal bir düzen oluşturabilme, gelişme, onur ve itibar kazanma gibi kendisine bahşedilen üstün ve ahlaki yetilerinden gelmektedir (Demir, 2000: 381-384).

Hangi açıdan ve düşünceden hareket edilirse edilsin insanın temel, değişmeyen ve diğer canlılardan ayrılan özellikleri bulunmaktadır. Bu özelliklerin başında akıl gelmektedir. Yani insanı diğer canlılardan ayıran en önemli özelliği akıl sahibi olmasıdır. $\mathrm{Bu}$ durum insanın gerek bireysel yaşamında gerekse toplumsal yaşamda diğer canlılarla olan ilişkisini düzenleyen temel unsurdur. Aklın yanı sıra insanın vicdanlı bir varlık olması da oldukça önemlidir. Zira vicdan terazisinde tartılmadan sergilenen davranışlar eksik kalmakta ve insanın ahlaki yetkinliğe ulaşması zorlaşmaktadır.

İnsan sosyal bir varlık olması nedeniyle toplumsal bir yaşam sürmek zorundadır. Toplumsal yaşamda ise bir mecburiyet olarak ihtiyaçlarını karşılayabilmek için birbirleriyle yardımlaşma, işbirliği, iş bölümü ve paylaşma gibi ilişkiler içerisinde bulunmaktadır (Denek, 2010: 33). Bu durum insanların sosyal kurumlar oluşturmalarını ve bu kurumlar eliyle ihtiyaçlarını karşılamalarını beraberinde getirmiştir. Kamu yönetimi de insanların ihtiyaçlarını karşılamak amacıyla oluşturmuş oldukları en önemli kurumdur. Esasen insanlar ihtiyaçlarını bu kurumlar aracılığıyla yine insan eliyle karşılamaktadır. Yani kamu yönetiminin temelinde insan ve insan faaliyetleri bulunmaktadır. Öyle ki insanın olmadığ 1 bir yönetimde ihtiyaçların giderilmesi mümkün değildir. Böylesi bir anlayış insansız bir kamu yönetiminin mümkün olamayacağını göstermektedir.

İnsan unsuru kamu yönetiminde kamu görevlisi olarak ifade edilmektedir. Kamu görevlisini hem dar hem de geniş anlamda tanımlamak mümkündür. Dar anlamda kamu görevlisi, devletin siyasal yapısını oluşturan görevliler dışında kalan asker ve sivil tüm çalışanları kapsamaktadır. Geniş anlamda kamu görevlisi ise devlet idaresindeki tüm kurumlarda çalışan ve hukuki durumları itibariyle birbirlerinden farklı olan tüm görevlileri ifade etmektedir (TODAİE, 1987: 54; Akgüner, 2014: 40).

Her ülkede sosyal refah devleti anlayışının bir zorunluluğu olarak üretilmesi gereken mal ve hizmetlerin büyük bir kısmı kamu görevlileri eliyle yerine getirilmektedir. Bu durum kamu görevlilerinin bütün ülkelerde istihdamın önemli bir kısmını oluşturmasını sonuç vermiştir (Tutum, 1990: 32). Kamu görevlisine artan ihtiyaç günümüzde daha da fazla bir hale gelmiştir. Zira zamanında düşünülmeyen ve akla gelmeyen yeni, karmaşık ve çeşitli hizmet alanları ortaya çıkmakta ve bu hizmetlerin devlet tarafindan yerine getirilmesi istenmektedir. Bu nedenle genelde devletin, özelde ise kamu yönetiminin hem sosyal düzenin sürdürülmesi hem de ülkenin ekonomik ve sosyal gelişmesinin sağlanması gibi birçok görevi ortaya çıkmakta ve bu görevler yaşanan gelişmelerle birlikte de sürekli artmaktadır (Tortop, 1986: 33-34). Dolayısıyla 
kamu görevlilerinin kamu yönetimi içerisindeki yeri de gittikçe önemli hale gelmektedir.

Kamu yönetiminde başarının ve verimin en önemli unsurunu insan oluşturmaktadır (Erkin, 1969: 37). Bu nedenle bir kurumda sunulan mal ve hizmetlerde verimliliğin elde edilebilmesi, personele tevdi edilen görevlerin yerine getirilip getirilmemesine bağlıdır. Böylesi bir durum, kamu yönetiminde görevli personelin görevin gerektirdiği niteliklere sahip olmasını gerektirmektedir. Kamu görevlisinin üzerine düşen sorumluluklarını en iyi şekilde yerine getirmesi ise ahlaki bir bakış açısını zorunlu kılmaktadır. Zira kamu yönetiminde ahlaki faziletleri kendisinde bulundurmayan bireyler kamu yönetiminin faaliyetlerinin aksamasina ve gerek kamusal gerekse toplumsal yaşamda birçok sorunun yaşanmasına neden olmaktadırlar. Dolayısıyla verimli bir kamu yönetimi için yetiştirilen kamu personelinin ahlaki niteliklere sahip olması gerekmektedir. Bu açıklamalar ışığında çalışmanın bir sonraki başlığında kamu yönetimi için nitelikli personel yetiştirmede ahlakın rolü ve önemi tartışılacaktır.

\section{AHLAKIN NITELIKLİ KAMU GÖREVLISI YETIŞTIRMEDEKI ROLÜ}

Kamu yönetiminde sunulan hizmetler önemli ve büyük işlerdir. Lakin bunlardan önce aşılması gereken önemli bir adım vardır. Bu ise ahlaktır. Ülken'e (2017: 82) göre esas büyük iş önce ahlaklı olmaktır. Zira ahlaki olgunluğunu sağlayamamış bireylerin gerçekleştireceği işler eksik kalacak ve vatandaşlara faydası da kısıtlı olacak veya hiç olmayacaktır. Faydanın maksimize edilmesi yalnızca işin icra edilmesi ile değil ahlaki niteliklere sahip bireyler tarafından, yapılacak işin doğasına uygun şekilde yapılması demektir.

İnsan her şeyden önce ve en önemli vasfi ile ahlaki bir varlıktır (Ülken, 2017: 1). Ahlak bireyin kendisi, çevresi, toplumu ve dünyası ile kurduğu anlamlı bağdır. Birey ancak ahlak ve ahlakilik ekseninde eylemde bulunduğu zaman sosyal bir varlık olabilir ve ancak ahlak sayesinde sosyal yapı içinde varlığını sürdürebilir. Bireyin yaşantısında ve her türlü uğraşında ahlak belirleyicidir ve bireyin eylemde bulunmasına olanak veren yegane güçtür. Eğer insan ahlaktan mahrum ise, yaşantısı, yaptığı iş ve her türlü eylem problemli bir hale gelir (Gündüz, 2016: V).

Dünya sorunları doğru ve dikkatli bir şekilde tahlil edildiğinde, çoğunun temelinde ahlaki bozulmaların ve çürümelerin olduğu görülecektir. İktisadi, politik, kültürel ve sosyal buhranlar, önemli ölçüde ahlaki bunalımlarla bağlantılıdır. Ahlakın yitirildiği bir dünyada her türlü problemin vuku bulmas1 mümkündür (Gündüz, 2016: VI). Bu durum özellikle kamu yönetimi için ayrıca önem taşımaktadır. Zira yitirilmiş gerçek ahlaki duyguların en yaygın görüldüğü alanlardan birisi kamu yönetimidir. Çünkü kamu yönetimi, bütün vatandaşlar adına hareket eden ve onlara hizmet etmekle mükellef olan bir varlıktır. Dolayısıyla bu alanda ortaya çıkacak gayri ahlaki davranışlar yozlaşmanın ve bozulmanın toplum açısından geldiği son noktayı gösterir (Yüceol, 2014: 30). 
Kamu yönetiminde ahlak, kamu görevlilerinin davranışlarında somutlaşmaktadır. Kamu görevlileri kamu kaynaklarının yönetimi konusunda vatandaşlarla bağ kurarak yetkilerini kullanırlar ve görevlerini yerine getirirler. Kamu görevlileri bu hususta yasaların uygulanmasından, topluma hizmetten, demokrasiyi korumaktan ve kamu kaynaklarının korunmasından sorumludurlar. Vatandaşlarla var olan bağın korunması, sayılan diğer yükümlülüklerin yerine getirilmesi ve kamu gücünün keyfi kullanılmaması için ahlaki yükümlülükler bir denge unsuru olarak var olmak zorundadır. $\mathrm{Bu}$ yapılmadığı sürece kamu yönetiminde yaşanan bozulmaların ve her türlü sorumsuz davranışın önüne geçmek mümkün değildir (Yüceol, 2014: 32).

Şüphesiz ki kamu görevlilerinin davranışlarına yön veren temel unsur yasalardır. Yani kamu yönetiminde sorumluluklar önceden belirlenmiş kurallar doğrultusunda yerine getirilmektedir (Usta, 2010: 169). Lakin kamu yönetiminde tüm eylem ve işlemlerin yasalar çerçevesinde yerine getirilmesi mümkün değildir. Ayrıca tüm işlemlerde yasalara bağlı kalmak kırtasiyeciliğe neden olmakta ve işlemlerin gecikmesini beraberinde getirmektedir. Bu nedenle kamu görevlilerine görevlerin kesintisiz bir şekilde işlemesi için geniş bir takdir yetkisi tanınmıştır (TUSİAD, 2003: 21; Çevikbaş, 2006: 271). Kamu yönetiminde kesintisiz ve verimli bir hizmetin sunulması amacını taşıyan takdir yetkisi, gayri ahlaki kriterlerden yoksun bir şekilde kullanılabilmektedir. Bu durum kamu yönetiminin başarısız olmasına ve takdir yetkisinin beklenenin tam tersi bir etkide bulunmasina neden olabilmektedir (Erbay, 1997: 408).

Esasen kamu yönetiminde kamu görevlilerinin davranışlarına yön veren temel iki unsur bulunmaktadır. Bunlardan biri yasalar, diğeri ise ahlaktır. Yasalar kamu görevlilerinin davranışları üzerinde dışsal bir denetim ve denetleme aracı olarak faaliyet gösterirken, ahlak, içsel bir yönlendirme ve denetleme sağlamaktadır (Yılmaz, 2014: 265; Apa ve Öktem, 2014: 60). Kamu yönetiminde her ne kadar yasal düzenlemelerle dışsal denetim sağlanmaya çalışılsa da dışsal kontrol araçlarının etkinliği tartışmalıdır. Çünkü hukuk kurallarının var olması her zaman bu kurallara uyulduğu anlamına gelmemektedir (Akıllı vd., 2013: 6; Koçberber, 2008: 68). Dolayısıyla burada önemli olan personelin ahlaki karakterini geliştirmesidir (Demirci ve Genç, 2008: 47-48). Çünkü bireye gerçek değerini veren ve onu yükselten ruhsal yetkinliktir. Ruhsal yetkinliğe erişmiş insan özdenetimini sağlayabilen ve akli melekelerini tutkularından üstün tutan insandır. Özdenetim sahibi bir insan erdemli bir insandır. Bu nedenle ahlaki davranışların kaynağında içsel unsurlar, dışsal unsurlara göre daha önemlidir (Cihan, 2009: 731). Yani ahlak, kamu yönetiminde yasalardan önce var olmas1 gereken ve aynı zamanda yasaların başarılı bir şekilde uygulanmasında kritik bir rol oynayan oldukça önemli bir olgudur. Dolayısıyla kamu yönetimi ile ilgili yasal düzenlemelerin gözden geçirilmesi ve ahlaki temelde düzenlemelerin yapılması önem arz etmektedir.

Ahlaken çökmüş olan insanlardan oluşan bir gruptan ideal toplumu oluşturabilecek dahice hazırlanmış bir plan veya bir reçete bulunmamaktadır. 
Böyle bir toplum, her firsatı ahlaksız şahsiyetini ortaya koymak için değerlendirecektir. İnsan toplumunun düzeni her şeyden önce insan terbiyesi üzerinde durmaktadır (İzzetbegoviç, 2010: 63). Yani temel problem ahlaklı olup olmamak ve ahlaki faziletlerin kazanılmasıdır. Ahlak, insanın var olmasının doğal bir parçasıdır ve mutlaka geliştirilmesi gerekir (Zengin, 2016: 5). Bu ise bir eğitimi gerektirmektedir. Kamu yönetiminde kamu personelinin görevlerini daha iyi bir şekilde yerine getirmeleri amacıyla hizmetiçi eğitim verilmektedir. Verilen eğitimin ahlaki bir nitelik arz etmesi oldukça önemlidir. Theodore Roosevelt, bir insanı ahlaken eğitmeden sadece zihnen eğitmenin, topluma bir bela kazandırmak olduğunu ifade etmiştir. Zira salt anlamda eğitim bedeni, ahlak ise ruhu ifade etmektedir. Ahlaktan yoksun bir eğitim, ruhsuz bir bedendir ve ruh bulunmayan her şey ölü, cansız ve bereketsizdir. Ahlaki olmayan bir eğitim zulüm, haksızlık, şiddet ve yozlaşmanın ortaya çıkmasına neden olur (Arıcan, 2015: 25). Bu nedenle eğitim mutlaka ahlaki bir nitelik arz etmelidir. Bunun örneklerini tarihte ahlaklı bireyler yetiştirmek için eserler bırakmış düşünürlerde bulabilmekteyiz. Türkiye'nin yönetim tarihinde önemli etkileri bulunan Koçi Bey Risaleleri, Nizamülmülk'ün Siyasetnamesi, Farabi’nin Erdemli Şehri gibi eserlerin üzerinde durduğu temel nokta; ahlaklı insanların, çalışanların ve yöneticilerin yetiştirilmesi ve bunun sonucunda ahlaklı bir devlete veya kamu yönetimine geçilmesidir (Gündoğdu, 2015: 43). Bunun sağlanamaması durumunda kamu yönetiminin amacı doğrultusunda faaliyet göstermesi mümkün olamamaktadır.

Eğitim noktasında dikkat edilmesi gereken önemli bir husus, ahlak eğitiminin bilgiden ziyade eyleme dayalı olmasıdır. İbn Miskeveyh, insana has mükemmelliğin bilmek ve yapmak üzerine odaklandığını ifade ederek, bilginin suret, uygulamanın ise mükemmellik olduğunu belirtmiştir. İbn Miskeveyh'in ifade ettiği mükemmellik, ahlaki bir mükemmelliktir ve bu ise ancak ahlaki bilginin uygulanması ile mümkündür (İbn Miskeveyh, 2017: 60-61). Dolayısıyla iyinin bilinmesi yetmez, onun tatbiki esastır. Yani fazilet bilgisine sahip olmak değil, onu yaşatmak gerekir (Topçu, 2014a: 20). Bilginin son evreye ulaşmasını ve evrensel bir düzen halini almasını ahlak olarak ifade eden Sokrates (Arslan, 2006: 130), ahlakın ancak uygulama ile gerçekleşebileceğini hayatı ile bizlere göstermiştir. Zira onun erdeme ve erdemli yaşama verdiği önem idam edilmesi ile sonuçlanmış̧ır.

Ayrıca ifade etmek gerekir ki eyleme dayalı eğitim beraberinde sorumluluk duygusunun da gelişmesini sağlamaktadır. Sorumluluk duygusu oldukça önemlidir. Çünkü ahlak olgusunun kaynağında sorumluluk duygusu bulunmaktadır. Diğer bir ifade ile ahlak, sorumluluk iradesinin bir tecellisidir (Topçu, 2015b: 22). Sorumluluk harekete geçirici bir kuvveti ifade ederken (Gündoğdu, 2015: 32; 38), mesul olmayı da gerekli kılmaktadır. Mesul olmayanlar zulüm yolunu kendileri için hep açık bulacaklardır. Mesul olanlar ise yarın hesabını verecekleri hareketlerini her zaman ahlak ölçüsünde icra etmek mecburiyetini hissedeceklerdir (Topçu, 2014b: 158). Bu nedenle kamu yönetiminde personele verilecek olan eğitimin uygulamaya dayalı ve sorumluluk aşılayıcı bir eğitim olması gerekmektedir. 
Kamu yönetiminin ahlaki bir yapıya kavuşturulmasında bir diğer önemli husus, kamu görevlilerinin ahlaki davranışlarda 1srarcı olmasıdır. Güngör'e göre, ahlakın taviz vermeye tahammülü yoktur. Bu konuda zayıf davranmak veya prensiplerden fedakarlık yapmak, beraberinde büyük fedakarlıkların gelmesine neden olacaktır (1997: 69). Böylesi bir durum kamu yönetiminin zaman içerisinde ahlaken yozlaşmasını beraberinde getirecektir. Bunun engellenebilmesi için özellikle kamu yöneticilerinin ahlaki davranışlar konusunda ısrarcı olmaları ve personelini bu konuda istekli kılmaları gerekmektedir.

Kamu görevlilerinden en genel anlamı ile görevlerinin gerektirdiği şekilde karar almaları ve bu kararları kamu yararı doğrultusunda uygulamaları beklenmektedir. $\mathrm{Bu}$ beklentiler içinde görev yapan kamu görevlileri arasında birçok ikilem ve çıkmaz ortaya çıkabilmekte ve bu durum kararlarını etkileyebilmektedir (Usta, 2011: 45). Bu çıkmazlar sonucunda kamu görevlilerinin ahlaki bir değer olan vazifelerini yapmak yerine gayri ahlaki davranışlarda bulunmasında etkili olan unsurların başında şüphesiz ki menfaat gelmektedir. Platon'a göre, yönetimde bulunan hiç kimse, bir yönetici olarak görevinde kalmaya devam ettiği süre içerisinde kendi çıkarlarına uygun olan şeyleri gözetemez. Kamu personeli, sadece yönetiminde bulunan kişilerin faydasını gözetmek durumundadır. Öyle ki konuştuğu her kelimede ve yaptığı her şeyde yalnızca bunu göz önünde bulundurmalıdır (2016: 35-36). Dolayısıyla ifade etmek gerekir ki, vazife ile menfaat birbirinin zıddıdır. Aralarında kaide olarak hiçbir benzerlik bulunamaz. Vazife hiçbir zamana menfaatçi değildir, menfaatin ise ahlak ile alakası yoktur (İzzetbegoviç, 2011: 159). Kamu yönetiminde temel amaç kamu yararıdır. Mesleğin icrasından kaynaklanan gelir, maaş, güç, statü gibi kişisel yararlar kamu görevi için ikinci planda kalmalıdır (Yüceol, 2014: 31).

Ancak ahlaklı bireylerden oluşan bir kurumda iş ahlakı kuralları işleyebilmektedir. Topçu'ya göre iş ahlakına sahip olmayan bireyler ne kadar çalışırlarsa çalışsınlar aslında işsizdirler. Bu insanlar hangi kurumda ve hangi konumda bulunurlarsa bulunsunlar topluma faydalı olmadıkları gibi, çoğu zaman toplum için birer zararlı varlıklar veya musibetler halini alırlar (Topçu, 2015c: 33). Bu durum kamu görevlileri için ahlakın edinilmesi gereken temel unsur olduğunu göstermektedir. Zira insanların yaşamlarında oldukça önemli olan ve faaliyetleri ile insanları doğrudan etkileyen kamu yönetiminin faydalı bir hale gelebilmesi, kamu personelinin ahlaki faziletlere sahip olmasını gerektirmektedir.

Ahlakın gayesi yaşamak değil, yaşatmaktır (Güngör, 1997: 47). Kamu yönetimi vatandaşlar için vardır ve varlık amacı da vatandaşlara hizmet etmektir. Yani kamu yönetimi de tıpkı ahlak gibi, yaşamak değil yaşatmak amacını taşımaktadır. Bu amaca aykırı gerçekleşen her durum kamu yönetiminin yozlaşmasına ve amacından sapmasına neden olmaktadır. Dolayısıyla genelde kamu yönetiminin ve özelde ise kamu personelinin sorumluluklarını en iyi şekilde yerine getirebilmesi ahlaki bir bakış açısını zorunlu kılmaktadır. Ahlak bireysel anlamda yetkinliği sağlayarak kemal bir kamu yönetiminin ve nihayetinde kemal bir devletin oluşmasını sağlayabilecek yegane unsurdur. Platon'un, Farabi'nin, 
Kınalızade Ali Çelebi'nin, Nizamülmülk'ün ve diğer birçok düşünürün oluşturmak istediği ideal devlet yapısı veya erdemli devletleri, aynı temel kaide üzerinde odaklanmıştır: Bireysel yetkinlikten erdemli devlete.. Bu süreç oldukça geniş ve uzun bir dönemi kapsayan zor bir süreçtir. Lakin temel nokta bireyden geçmektedir. Önce bireysel boyutta ahlaki yetkinlik sağlanmalıdır. Dolayısıyla ifade edilebilir kamu yönetiminde nitelikli personel yetiştirmenin yolu, ahlaktan veya bireysel anlamda ahlaki yetkinliğe ulaşmaktan geçmektedir.

\section{SONUÇ}

Kamu yönetimi vatandaşların ihtiyaç duyduğu hizmetleri üreten en önemli kurumdur. Kamu yönetiminin amacı doğrultusunda verimli bir şekilde faaliyet göstermesi onun ahlak ile olan bağının güçlenmesi ile yakından ilişkilidir. $\mathrm{Bu}$ ise ahlaki yetkinliğe ulaşmış bireylerin kamu yönetiminde varlığı ile mümkündür. Zira ahlaktan yoksun insanların bulunduğu bir yönetimin faydalı olması beklenemez.

Kamu yönetiminde nitelikli personel yetiştirmek için gerekli olan ahlak ile ilgili olarak atılması gereken birçok önemli adım bulunmaktadır. Bunlardan ilki kamu yönetiminde var olan mevzuatın ahlak eksenli gözden geçirilmesi ve eksiklerin giderilmesi gereğidir. Kamu görevlileri üzerinde dışsal bir denetim mekanizması olan yasaların, içsel bir denetim mekanizması olan ahlak ile bütünleştirilmesi, kamu personelinin davranışlarının kontrol edilmesinde oldukça etkili olacaktır.

İkinci atılması gereken önemli adım, kamu görevlilerine ahlak temelinde hizmetiçi eğitim verilmesidir. Ahlak bilgi ile var olan bir olgudur. Kamu görevlilerinin bazı durumlarda sergilemiş oldukları davranışların ahlaki olup olmadıklarını bilmedikleri ve dolayısıyla gayri ahlaki davranışlarda bulundukları durumlar bulunmaktadır. Bunların engellenebilmesi için ahlaki faziletlerin kendilerine öğretilmesi gerekmektedir. Yine eğitimlerin salt bilgiden ziyade uygulamaya dayalı olması ve sorumluluk aşılayıcı bir nitelik ifade etmesi oldukça önemlidir. Zira uygulanmayan bilginin davranışa ve zamanla karaktere dönüşmesi mümkün değildir.

Üçüncüsü kamu yönetiminde ahlak konusunda 1srarcı olmak ve ahlaki davranışlardan taviz vermemek gereğidir. Çünkü ahlak konusunda verilecek tavizler büyük kurumsal ve toplumsal bozulmalara neden olabilecek niteliktedir.

Dördüncüsü ahlaklı olmanın öneminin kamu görevlilerine hatırlatılmasıdır. Kamu yönetimi ahlaki amaçlar barındıran ve toplumu doğrudan etkileyen önemli bir olgudur. Ahlaklı olmanın veya olmamanın olumlu ve olumsuz sonuçları konusunda kamu personelinin bilgi sahibi olması, yaptıkları davranışların vatandaşları ve devleti ne kadar etkilediğinin ortaya konması gerekmektedir.

Bir diğer önemli husus ise bireysel menfaatler ile kamusal menfaatler arasında bir dengenin kurulmasının sağlanmasıdır. Kamu yönetimi kamu yararı amaciyla faaliyet göstermektedir. Bireysel menfaatlerin toplum menfaatlerinden önce tutulması gayri ahlaki bir davranış olarak kamu yönetimine oldukça büyük 
zarar vermektedir. Bu durumun giderilebilmesi, yani kamu yararının bireysel menfaatlerden önce tutulması ise ancak ahlak ile mümkündür.

Unutmamak gerekir ki kamu yönetiminin başarı düzeyi ile toplumsal refahın gelişmesi arasında doğrusal bir ilişki bulunmaktadır. $\mathrm{Bu}$ ise kamu yönetiminin çok önemli bir unsuru olan insan unsuru ile yakından bağlantılıdır. Kamu yönetiminde başarının anahtarı nitelikli personeldir. Nitelikli personel olmanın çok önemli bir boyutunu ise ahlak oluşturmaktadır. Zira ahlak varlığı ile her şeyi anlamlı ve doğasına uygun bir şekilde başarılı kılan yegane unsurdur.

\section{KAYNAKÇA}

Akarsu, B. (1998). Felsefe Terimleri Sözlügü. İstanbul: İnkılap Kitabevi Yayınları.

Akgüner, (2014). Kamu Personel Yönetimi. İstanbul: Der Yayınları.

Akıllı, H. S. Çam, S. Kılınç, S. ve Kızılboğa, R. (2013). Kamu Personelinin Etik İhlallerine Verdikleri Önem Derecesi ve Etik İhlallerin Bildirimi Konusundaki Görüşleri. Sayıştay Dergisi, (89), 5-33.

Akseki, A. H. (2016). Ahlak Dersleri. Ankara: Diyanet İşleri Başkanlığı Yayını.

Apa, Y. ve Öktem, M. K. (2014). Kamu Hizmeti Değerlerine İlişkin Kavramsal Bir Analiz. Uluğ, F. Ertan, K. A. ve Özgen, H. (Ed.), Kamu Etiği Seçilmiş Kongre Bildirileri, Ankara: TODAİE Yayın1, 60-77.

Aral, V. (2014). İnsan ve Norm. İstanbul Üniversitesi Hukuk Fakültesi Mecmuas1, 72(1), 17-42.

Arıcan, M. K. (2016). Ahlak, Etik ve Ahlak Felsefesi. Yıldırım Beyazıt Üniversitesi Uluslararası İlişkiler ve Stratejik Araştırmalar Enstitüsü Bülteni, 11-23.

Arslan, A. (2006). İlkçağ Felsefe Tarihi II-Sofistlerden Platon'a. İstanbul: İstanbul Bilgi Üniversitesi Yayınları.

Aydın, A. H. (2016). Kamu Yönetimine Giriş. Ankara: Seçkin Yayıncılık.

Bozkurt, Ö. Ergun, T. ve Sezen, S. (1998). Kamu Yönetimi Sözlüğ̈̈. Ankara: TODAİE Yayınları.

Bulut, M. (1996). Sosyolojik Açıdan Ahlak ve Ahlak Eğitimi. Diyanet İlmi Dergi, 32(1), 97-105.

Cevizci, A. (2018). Etik-Ahlak Felsefesi. İstanbul: Say Yayınları.

Cihan, M. (2009). Sokrates ve Etik Eğitimi, Kamu Etiği Sempozyum Bildirileri 2. Ankara: TODAİE Yayın1, 722-732.

Comte-Sponville, A. (2006). Felsefeyi Takdimimdir. (Çev. Yılancığlu, S. S.), İstanbul: Altın Kitaplar Yayınevi.

Çevikbaş, R. (2006). Yönetimde Etik ve Yozlaşma. Atatürk Üniversitesi İktisadi ve İdari Bilimler Dergisi, 20(1), 265-289.

D’Alembert, (2000). Felsefenin Öğeleri. (Çev. Köse, H.), İstanbul, Öteki Yayınları.

Demir, N. (2000). İnsan Hakları Semantiğine Düşünsel Bir Yaklaşım Denemesi. Cumhuriyet Üniversitesi İlahiyat Fakültesi Dergisi, 4(1), 375-399.

Demirci, M. ve GENÇ, F. N. (2008). Türkiye'de Kamu Yönetimi Reform Sürecinde Etik Yapılanma. Amme İdaresi Dergisi, 41(2), 43-58.

Denek, M. N. (2010). İslam, Eşitlik ve Sosyal Adalet. Ankara: Phoenix Yayınevi.

Doğan, S. (2014). Uygarlık Merkezli Ahlak ve Adalet Eğitimi Yaklaşımı. Bitlis Eren Üniversitesi Sosyal Bilimler Enstitüsü Dergisi, 3(1), 111-126.

Erbay, Y. (1997). Bürokrasi, Bürokratizm ve Ülkemizde Bürokrat-Siyasetçi İlişkileri. Yeni Türkiye Dergisi, (13), 405-412.

Erdem, H. (1990). Dini Ahlak ve İlahi Dinlerden Yahudilik, Hıristiyanlık ve Müslümanlık'daki Bazı

Ahlaki Meselelere Mukayeseli Bir Yaklaşım. Selçuk Üniversitesi İlahiyat Fakültesi Dergisi, (3), 225-254.

Erkin, V. (1969). İdarede Verim ve Personel Meseleleri. Amme İdaresi Dergisi, 2(3), 37-50.

Eryılmaz, B. (2015). Kamu Yönetimi, Kocaeli: Umuttepe Yayınları.

Gözübüyük, Ş. (2015). Türkiye'nin Yönetim Yapısı. Ankara: Turhan Kitabevi Yayınları. 
Gündoğdu, A. (2015). Eğitim ve Ahlak Şurası Açılış Konuşmaları. Arıcan, M. K. Orçan, M. Kala, M. E. Cizreli, B. ve Sağlam, M. K. (Ed.), Eğitim ve Ahlak Şurası "Mehmet Akif İnan Hatırasına", Eğitim-Bir-Sen Yayınları, 33-45.

Gündüz, M. (2016). Ahlak Sosyolojisi, Ankara: Anı Yayıncılık.

Güngör, E. (1997). Ahlak Psikolojisi ve Sosyal Ahlak. İstanbul: Ötüken Yayınları.

Heimsoeth, H. (1978). Ahlak Denen Bilmece. (Çev. Uygur, M.), İstanbul: İstanbul Üniversitesi Edebiyat Fakültesi Yayınları.

İbn Haldun, (2011). Mukaddime I-II. Haz. Uludağ, S. İstanbul: Dergah Yayınları.

İbn Miskeveyh (2017). Tehzîbu'l Ahlak. (Çev. Şener, A. Tunç, C. ve Kayaoğlu, İ.), İstanbul: Büyüyenay Yayınları.

İzzetbegoviç, A. (2010). İslami Yeniden Doğuşun Sorunları. (Çev. Ademi, R.), İstanbul: Fide Yayınları.

İzzetbegoviç, A. (2011). Doğu Batı Arasında İslam. (Çev. Şaban, S.), İstanbul: Yarın Yayınları.

Kalın, İ. (2015). Akıl ve Erdem. İstanbul: Küre Yayınları.

Koçberber, S. (2008). Dünyada ve Türkiye'de Denetim Etiği. Sayıştay Dergisi, (68), 65-89.

Mahfuzi, A. A. (2015). Temel İlkeleriyle Ahlak. İstanbul: Tesnim Yayınları.

Meriç, C. (2008). Kırk Ambar I. İstanbul: İletişim Yayınları.

Özlem, D. (2004). Etik-Ahlak Felsefesi-. İstanbul: İnkılap Yayınları.

Parlak, B. (2016). Yönetim Bilimi ve Çağdaş Yönetim Teknikleri. İstanbul: Beta Yayınları.

Platon, (2016). Devlet. (Çev. Alagöz, E.), Ankara: Panama Yayınları.

Şeriati, A. (1997). İnsanın Dört Zindanı. (Çev. Hatemi, H.), İstanbul: İşaret Yayınları.

Timuçin, A. (2010). Felsefeye Giriş. İstanbul: Bulut Yayınları.

TODAİE, (1987). Devlet Memurları El Kitab1.

Topçu, N. (2014a). İsyan Ahlakı. İstanbul: Dergah Yayınları.

Topçu, N. (2014b). İradenin Davası. Devlet ve Demokrasi, İstanbul: Dergah Yayınları.

Topçu, N. (2015a). Ahlak. İstanbul: Dergah Yayınları.

Topçu, N. (2015b). Ahlak Nizamı. İstanbul: Dergah Yayınları.

Topçu, N. (2015c). Yarınki Türkiye. İstanbul: Dergah Yayınları.

Tortop, N. İsbir, E. G. Aykaç, B. Yayman, H. ve Özer, M. A. (2017). Yönetim Bilimi. Ankara: Nobel Yayınları.

Tortop, N. (1986). Personel Yönetimi İle İlgili Bazı Kavramların Anlamı ve Uygulanması. Amme İdaresi Dergisi, 19(3), 31-42.

Turan, E. (2016). Kamu Yönetimi. Konya: Palet Yayınları.

TUSİAD, (2003). Kamu Hizmetinde Etik. İstanbul: TUSİAD Yayını.

Tutum, C. (1990). Kamu Personeli Sorunu. Amme İdaresi Dergisi, 23(3), 31-45.

Uludağ, S. (2018). İslam'da Ahlak ve Ahlak Ekolleri. İstanbul: Sufi Kitap.

Usta, A. (2010). Kamu Görevlisinin Etik Amaç ve Ahlaki Yükümlülüğüne Yönelik Bir Değerlendirme. Türk İdare Dergisi, (468), 159-181.

Usta, A. (2011). Kuramdan Uygulamaya Kamu Yönetiminde Etik ve Ahlak. Kahramanmaraş Sütçü İmam Üniversitesi İktisadi ve İdari Bilimler Fakültesi Dergisi, 1(2), 39-50.

Ülken, H. Z. (2017). Aşk Ahlakı, İstanbul: Türkiye İş Bankası Kültür Yayınları.

Ünsal, A. (2017). Hemşireliğin Dört Temel Kavramı: İnsan, Çevre, Sağlık\&Hastalık, Hemşirelik. Ahi Evran Üniversitesi Sağlık Bilimleri Dergisi, 1(1), 11-25.

Yılmaz, E. G. (2014). Kurumsal Bilgileri İ́şa (Whistleblowing): Kamusal Sadakat mi Kurumsal İhanet mi? Kamu Kurumları Açısından Bir Teorik Tartışma. Uluğ, F. Ertan, K. A. ve Özgen, H. (Ed.), Kamu Etiği Seçilmiş Kongre Bildirileri, Ankara: TODAİE Yayını, 254 270 .

Yüceol, H. M. (2014). Kamu Etiğinin Ekonomi Boyutu ve Ahlaki Ekonomi. Uluğ, F. Ertan, K. A. ve Özgen, H. (Ed.), Kamu Etiği Seçilmiş Kongre Bildirileri, Ankara: TODAİE Yayını, 2441.

Zengin, Z. S. (2016). İslam, Ahlak ve Etik. Yıldırım Beyazıt Üniversitesi Uluslararası İlişskiler ve Stratejik Araştırmalar Enstitüsü Bülteni, 5-10.

http://www.tdk.gov.tr/index.php?option=com_gts\&arama=gts\&guid=TDK.GTS.5bf7ab84e0f165.84 427696 


\section{SUMMARY}

Morality, which focuses on what is good and what is bad in general, is quite effective in reaching individual competence and the creation of a healthy society. This situation is also applicable to the state, which people form together in order to address their needs, and public administration, which constitutes its most important executive tool.

Public administration functions as the face of the state reflected to citizens with the aim of fulfilling their basic needs. The functioning of public administration in the direction of its goals requires it to possess certain personnel. It is possible to list the personnel of public administration as officials of public, organization, public policy, norm order and financial resources. Undoubtedly, all of the aforementioned personnel are quite important for public administration and it can only serve its executive purposes with the presence of these personnel. However, the human element in public administration have always retained its importance and place within public administration for being an element that can affect all other factors and one that can make all other elements efficient or inefficient in the administrative process.

The human element is expressed in public administration as public personnel. In every country, a large part of the goods and services that must be produced as a necessity of the social welfare state mentality are provided through public personnel. This situation resulted in public personnel constituting a significant part of employment in all countries. The increasing need for public personnel has become even higher today. That is because new, complex and diverse areas of service that were not thought of before are emerging and the state is required to provide for these areas. For this reason, many new duties arise for the state in general and public administration in particular, such as maintaining the economic and social progress of the country, and these duties are constantly increasing with the developments that occur. Therefore, the place of the public personnel in public is becoming increasingly important.

Human beings are moral beings above all. Morality is the meaningful connection that the individual develops with himself and the world he is in. Human beings become social beings and sustain their existence within the social structure only by acting on the basis of morality. Therefore, morality is determinative in the life of individuals and their occupations. All actions performed by individuals who are deprived of morality are problematic.

The purpose of morality is not to live but to let live. Public administration exists for citizens and its purpose of being is to serve citizens as well. In other words, public administration, much like morality, carries the aim of letting live instead of living. Every situation that occurs contrary to this purpose results in the corruption of public administration and its deviation from its purpose.

Human beings constitute the most important element of success and efficiency in public administration. For this reason, acquiring efficiency in the goods and services that are presented in an institution depends on carrying out the 
tasks that were entrusted to the personnel. In such a case, it is required from the personnel in public administration to possess the required qualifications of the task. Morals are the leading qualifications that a public personnel should possess. Because individuals who do not possess moral virtues, cause public administration activities to disrupt and cause many problems both in public and in social life. Morals are quite affective in raising qualified personnel by providing self-competence and eventually creating a perfect public administration. In this study which would be conducted in the light of this information, first the concepts of morals and public personnel will be explained and then the role and the importance of morals in raising qualified personnel for public administration will be attempted to be revealed, in accordance with the "morals play a role in raising qualified personnel in public administration' hypothesis. 